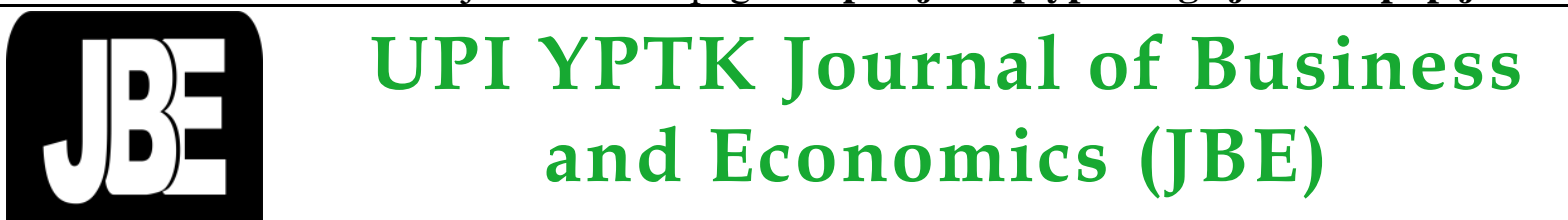

UPI YPTK JBE

\title{
Human Relations and Working Environment Conditions in Building A Work Ethic with Motivation as Mediation at The Office of Agency for Personnel and Human Resources Development (BKPSDM) Sawahlunto City
}

\author{
Nesyia Tri Khairani ${ }^{1}$, Marta Widian Sari ${ }^{2 *}$, Vivi Nila Sari ${ }^{3}$, Andry Novrianto ${ }^{4}$ \\ ${ }^{2,3}$ Management Doctoral Program Student, Faculty of Economics and Business, Universitas Putra Indonesia YPTK \\ ${ }^{14}$ Department of Management, Faculty of Economics and Business, Universitas Putra Indonesia YPTK \\ *martawidiansari@upiyptk.ac.id
}

\begin{abstract}
This research has a purpose to find out the influence of Human Relations and Work Environment Conditions in Building a Work Ethic with Motivation as Mediation at the Office of the Personnel and Human Resources Development Agency (BKPSDM) Sawahlunto City. The method used is Structural Equation Modeling (SEM) with Partial Least Square (PLS) 3.0. By distributing questionnaires as many as 39 respondents. The results of the data analysis concluded that there is a positive and significant influence concluded that there was a positive and significant influence on the human relation variable on the work ethic variable. There is a positive and insignificant influence on work environment variables on work ethic variables. There is a positive and no significant influence of the human relation variable on the motivation variable. There is a significant positive effect of the human relation variable on work ethic variables. There is a positive influence which is not significant. The motivation variable has an effect on work ethic variables. The human relation variable has a positive and insignificant influence on the work ethic variable mediated by motivation. There is a positive and insignificant influence given by the work environment variable on work ethic variables mediated by motivation.
\end{abstract}

Keywords: Human Relations, Working Environment, Work Ethic, Motivation, Human Resource Development

\section{Introduction}

Agencies or organizations have various instruments in achieving goals. These instruments include natural resources (raw materials), human resources (labor), technology, and capital. However, the most important tool is human resources, where humans are the most important driving factor of the organization's wheels (Sari, Novrianto, \& Widian, 2020). Concerning the organization's management in achieving its goals, the organization must be fully supported by interested parties in the organization, it is what is called "real goal guidance". The parties referred to here are managers or leaders of the organization and their subordinates or employees. It means that an organization or company must be able to create a synchronous and conducive atmosphere, where organizational leaders can cooperate with employees and direct organizational goals effectively so that employees feel that these goals are their goals or common goals. Based on the description above, an organization can achieve its goals because of the activities of the people who are members or employees in it. They can work well together based on a high work ethic (Suryadin \& Mistar, 2020), (Romi, Ahman, Disman, Suryadi, \& Riswanto, 2020). Work ethic is a work spirit based on certain values or norms (Faderika, 2016). The work ethic itself can be formed if an employee has the will to be able or able to do a job whose results can be satisfactory or very maximum. There are several factors that can influence the formation of a work ethic, among others, are wellestablished relationships between employees (human relations), the situation and conditions of the work environment itself, good work security and safety for employees, social conditions of the work environment, attention to a need. One's spiritual, physical, and selfesteem in the work environment, leadership factors, providing three fun incentives for employees (Najib \& Ramlawati, 2018).

The relationship between employees (human relations) in a company is very influential on the smooth running of the process of cooperation within 
the company, good relationships between leaders and subordinates make a job easier to understand and provide its own spirit to carry out a task and responsibility of each. The condition of the physical work environment can also affect work ethic. The conditions referred to include: cleanliness, lighting, ventilation, layout (especially the arrangement of tables, work chairs and cabinets), wall color, work equipment that is adequately maintained, and so on. In the world of work, employees or employees must have enthusiasm in their work. This spirit is one of the factors that can improve the performance of a company or agency. In other words, the spirit can be interpreted as his motivation to work (work motivation) (Mulyani, Sari, \& Sari, 2019). Work motivation is needed. This will make a performance in the organization can be better. An increase in work motivation will affect an increase in productivity and vice versa. The provision of motivation for each individual is different, and all of that can be adjusted to the circumstances and conditions in which the individual concerned is located (Wahyuningsih, Sukmawati, \& Basalamah, 2019). The Office of the Personnel and Human Resources Development Agency (BKPSDM) of Sawahlunto City serves and manages all personnel administration and human resource development in Sawahlunto City. Therefore, efforts to improve the quality of the workforce include the entire life of the organization that can be controlled by the leadership or by members of the organization concerned, the work environment, and strategies for achieving goals. Based on the results of observations of work ethic at the Office of the Agency for Personnel and Human Resources Development (BKPSDM) of Sawahlunto City, this can be seen from the table of achievement of annual activities of employees of the Office of the Office of the Office of Personnel and Human Resources Development (BKPSDM) of Sawahlunto City as follows:

Table. 1

Sawahlunto City BKPSDM Employee Annual Activities Achievements

\begin{tabular}{|c|c|c|}
\hline No & Tahun & \% \\
\hline 1 & 2017 & $88,40 \%$ \\
\hline 2 & 2018 & $91.58 \%$ \\
\hline 3 & 2019 & $89,73 \%$ \\
\hline
\end{tabular}

Source: Sawahlunto City BKPSDM Office

Based on the table above, it shows that the completion of work from 2017-2019 has not been fully realized, work completion in 2017 was still $11.6 \%$ less, in 2018 it fell to $8.42 \%$ and in 2019 it rose again by $10.27 \%$ to be able to meet the target. the Office has determined that, it will affect the employee's work ethic less than the maximum. And also from the results of the researcher's interview with one of the employees said that sometimes there are misunderstandings that occur between employees, so that employees in carrying out their duties cannot be optimal because there are misunderstandings that make employees uncomfortable to work. As a result, some work cannot be completed on time, by the quantity and quality determined by the company, meaning that the achievement of work targets is still not optimal. In addition, environmental conditions around the company, especially the physical environmental conditions, also affect employees' work ethic because it is undeniable that a safe, comfortable, clean and by the wishes of employees can create morale. However, the condition of the physical environment in this office is not sufficient, due to the lack of an office area that cannot accommodate 39 employees, to deal with this the employees only create workspaces per division with insulating limits, and the lighting in this office is still very minimal. , so that employees feel discomfort at work.

\section{Method}

This study uses quantitative methods. The quantitative method is a systematic scientific research on the parts and phenomena and the causality of their relationships (Sugiyono, 2016). The dependent variable in this study is work ethic, then the independent variable is human relations and works environment. Furthermore, motivation as an intervening variable. This type of research is a statement using a questionnaire as a tool to collect data. The number of samples used in this study was 39 employees at the Office of the Agency for Personnel and Human Resources Development (BKPSDM) Sawahlunto City. The statistical method used is Partial Least Square (PLS) (Sarstedt et al., 2020). Partial Least Square is a powerful analytical method because it is not based on many assumptions (Ringle, Sarstedt, Mitchell, \& Gudergan, 2020). As a data analysis technique, PLS uses Smart PLS Version 3 software specially designed to estimate structural equations based on variance. The Smartpls Version 3 program can be obtained at www.smartpls.de.

\section{Result and Discussion}

Analysis of the structural model or the so-called (inner model) which aims to test a hypothesis from the research conducted. This part that needs to be considered or analyzed in the structural model is the coefficient of determination (R-Square) and hypothesis testing. The coefficient of determination (R-Square) aims to estimate the accuracy of a model. In other words, this is to find out how variations influence a variation in the value of a variable in the 
value of the independent variable in the path model. Here are the R-Square values in the construction :

Table 2. Coefficient Determination Result Test

\begin{tabular}{cll}
\hline & R-Square & Adjusted R-Square \\
\hline Work Ethic & 0.632 & 0.601 \\
\hline Motivation & 0.389 & 0.355 \\
\hline
\end{tabular}

Source: Data Processed by Authors, 2021

The R-Square value of the Work Ethic Construct is 0.632 or $63.2 \%$ which describes the magnitude of the influence it receives from the job satisfaction construct from the Human Relations and Work Environment construct, while the R-Square value for the Motivation construct is 0.389 or $38.9 \%$ showing the effect given by Human Relations, Work Environment and Work Ethic in explaining or influencing Motivation.

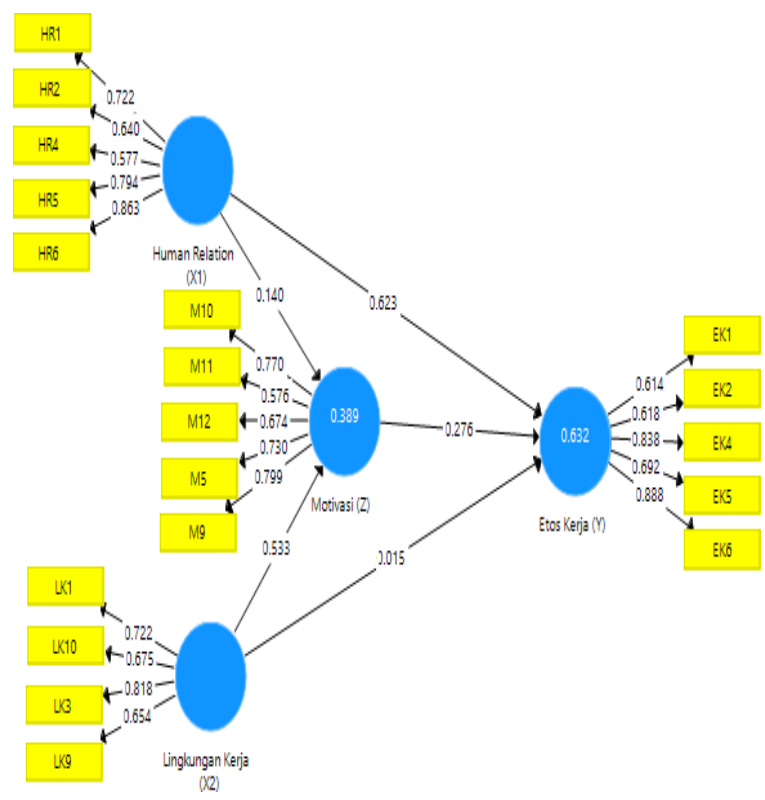

Figure 1. Analysis Test Result

In testing the hypothesis, there will be two stages of testing carried out, namely testing the direct influence hypothesis and the indirect effect hypothesis. This direct effect test aims to be able to prove the results of the hypothesis of a variable against other variables directly (without intermediaries). If the path coefficient value is positive, it indicates that an increase follows an increase in the value of a variable in the value of other variables. If the path coefficient value is negative, it indicates that a decrease follows an increase in the value of a variable in the value of another variable. If the probability value is feasible (P-Values) $<(0.05)$ then $\mathrm{HO}$ is rejected or the influence of a variable with other variables is significant. And if the probability value $(\mathrm{P}-$ Values $)>(0.05)$ then $\mathrm{H} 0$ is accepted then the effect of one variable with another is no significant.

Table 3

Direct Effect Hypothesis

\begin{tabular}{lcccc}
\hline & Original Sample (0) & $\begin{array}{c}\text { Standard } \\
\text { Deviation } \\
\text { (STDEV) }\end{array}$ & $\begin{array}{c}\text { T Statistics } \\
(\mathbf{O} / \text { STDEV] }\end{array}$ & P Values \\
\hline $\mathrm{X} 1>\mathrm{Y}$ & 0.623 & 0.181 & 3.450 & 0.001 \\
\hline $\mathrm{X} 2>\mathrm{Y}$ & 0.015 & 0.229 & 0.064 & 0.949 \\
\hline $\mathrm{X} 1>\mathrm{Z}$ & 0.140 & 0.166 & 0.845 & 0.399 \\
\hline $\mathrm{X} 2>\mathrm{Z}$ & 0.533 & 0.181 & 2.935 & 0.003 \\
\hline $\mathrm{Z}>\mathrm{Y}$ & 0.276 & 0.196 & 1.409 & 0.160 \\
\hline
\end{tabular}

Source: Data Processed by Authors, 2021

Based on table 3 above, it can be said that there is a significant relationship between $\mathrm{X} 1$ and $\mathrm{Y}$ with a T-statistic value of $3,450(<1.96)$. The original sample's value is positive, worth 0.623 which results indicate that the direction of the relationship between $\mathrm{X} 1$ and $\mathrm{Z}$ is positive. Thus, the hypothesis of $\mathrm{H} 1$ in this study is that human relationships have a positive and significant effect on work ethics or is intended, namely (Accepted). Both relationships between X2 and $\mathrm{Y}$ were not significant with a T-statistic value of 0.064 (> 1.96). The estimated value of the original sample is positive, which is 0.015 which indicates the result that the direction of the relationship between $\mathrm{X} 2$ and $\mathrm{Y}$ is positive. Thus, the hypothesis $\mathrm{H} 2$ in this study states that work environment factors have a positive and insignificant effect on work ethics or what is meant is (Rejected). the third relationship between $\mathrm{X} 1$ and $\mathrm{Z}$ was not significant with a Tstatistic value of $0.845(<1.96)$. The estimated value of the original sample is positive, that is, its value is 0.140 which indicates that the direction of the relationship between $\mathrm{X} 1$ and $\mathrm{Z}$ is positive. Thus the $\mathrm{H} 3$ hypothesis in this study which states that human relations has a positive and insignificant effect on motivation or is intended, namely (Rejected). The fourth, the relationship between $\mathrm{X} 2$ and $\mathrm{Z}$ is not significant with a T-statistic value of $2,935(<1.96)$. The estimated value of the original sample is positive, ie the value is 0.533 which indicates that the direction of the relationship between $\mathrm{X} 2$ and $\mathrm{Z}$ is positive. Thus, the hypothesis $\mathrm{H} 4$ in this study states that the work environment has a positive and significant effect on motivation or what is meant by (Accepted). Five relationships between $\mathrm{Z}$ and $\mathrm{Y}$ were not significant with a T-statistic value of 1.409 (<1.96). The estimated value of the original sample is positive, that is, its value is 0.276 which indicates that the direction of the relationship between $\mathrm{Z}$ and $\mathrm{Y}$ is positive. Thus, hypothesis $\mathrm{H} 5$ in this study states that motivation has a 
positive and insignificant effect on work ethics (Rejected).

\section{Conclusion}

From the results of research on human relations and working environment conditions in building a work ethic with motivation as a mediation at the Office of the Agency for Personnel and Human Resources Development (BKPSDM) of Sawahlunto City, it can be concluded that there is a positive and significant influence on the human relations variable on the work ethic variable. There is a positive and insignificant effect of the work environment variable on the work ethic variable. There is a positive and insignificant effect of the human relations variable on the motivation variable. There is a significant positive effect of the human relations variable on the work ethic variable. There is a positive and insignificant influence on the motivational variable on the work ethic variable. There is an insignificant positive effect given by the human relations variable on the work ethic variable mediated by motivation. There is an insignificant positive effect given by the work environment variable on the work ethic variable mediated by motivation.

The advice given is to better maintain human relations among employees in the office, especially in terms of cooperation, mental readiness, emotional control, and cultural background supported also by research from (Weatherburn, 2020), (Hartati, 2020), dan (de Alves \& Teixeira, 2020). For the head of the Office of the Personnel and Human Resources Development Agency (BKPSDM) of Sawahlunto City to pay more attention to the work environment such as lighting for office rooms, air temperature, noise, use of color, necessary space for movement, work security, and employee relations so that an environment can be created. conducive work environment so as to improve the work ethic of employees. The leadership is expected to be able to provide examples of work ethic attitudes, for example in terms of responsibility, high work spirit, discipline, diligence and seriousness, as well as maintaining dignity and honor among office employees. Leaders should master the aspects of Human Resources in their subordinates through persuasive leadership so that they can facilitate research and direction to each individual.

\section{References}

De Alves, D. A., \& Teixeira, W. M. (2020). Ethics in social sciences researches: Regulation, scientific practices and controversies. Educacao $e$ Pesquisa. $\quad$ https://doi.org/10.1590/S16784634202046217376

Faderika, A. B. (2016). Pengaruh Etos Kerja dan Kepuasan Kerja terhadap Produktivitas Kerja Karyawan di Pertenunan Desa Boro Kalibawang
Kabupaten Kulon Progo. Universitas Sanata Dharma.

Hartati, T. (2020). The Role of Human Relations in Increasing Employee Performance. Budapest International Research and Critics Institute (BIRCI-Journal) : Humanities and Social Sciences. https://doi.org/10.33258/birci.v3i1.726

Mulyani, S. R., Sari, V. N., \& Sari, M. W. (2019). The model of employee motivation and cooperative employee performance. Polish Journal of Management Studies, 20(2), 379-390. https://doi.org/10.17512/pjms.2019.20.2.32

Najib, R. O., \& Ramlawati, R. (2018). Analisis Dampak Human Relation dan Lingkungan Kerja Fisik Terhadap Etos Kerja Pegawai BPJS Kesehatan Cabang Makassar. JURNAL MANAJEMEN BISNIS. https://doi.org/10.33096/jmb.v5i2.34

Ringle, C. M., Sarstedt, M., Mitchell, R., \& Gudergan, S. P. (2020). Partial least squares structural equation modeling in HRM research. International Journal of Human Resource Management.

https://doi.org/10.1080/09585192.2017.1416655

Romi, M. V., Ahman, E., Disman, Suryadi, E., \& Riswanto, A. (2020). Islamic work ethics-based organizational citizenship behavior to improve the job satisfaction and organizational commitment of higher education lecturers in Indonesia. International Journal of Higher Education. https://doi.org/10.5430/ijhe.v9n2p78

Sari, M. W., Novrianto, A., Author, C., \& Widian, M. (2020). Analysis of the Influence of Changes in the Profession of the Bungus Fishing Community on the Quality of Human Resources in the Coastal Area of Padang City. 11(1), 150155.

Sarstedt, M., Ringle, C. M., Cheah, J. H., Ting, H., Moisescu, O. I., \& Radomir, L. (2020). Structural model robustness checks in PLSSEM. Tourism Economics. https://doi.org/10.1177/1354816618823921

Sugiyono, P. D. metode penelitian kuantitatif, kualitatif,dan R\&D. , Alfabeta, cv. (2016).

Suryadin, S., \& Mistar, M. (2020). Pengaruh Human Relation Dan Kondisi Lingkungan Terhadap Etos Kerja Karyawan Pada Kantor Unit Layanan Pengadaan (ULP) Woha. JURNAL SOSIAL EKONOMI DAN HUMANIORA. https://doi.org/10.29303/jseh.v6i1.68

Wahyuningsih, Sukmawati, \& Basalamah. (2019). Pengaruh Budaya Organisasi, Motivasi Kerja dan Etos Kerja Islam Terhadap Kinerja Karyawan Bank Syariah Mandiri Cabang Makassar. Center Of Economic Student Journal.

Weatherburn, M. (2020). Human Relations' invented traditions: Sociotechnical research and worker 
Nesyia Tri Khairani, Marta Widian Sari, Vivi Nila Sari, Andry Novrianto UPI YPTK Journal of Business and Economics (JBE) Vol. 7 No. 1 January (2022)

motivation at the interwar Rowntree Cocoa

Works. Human Relations.

https://doi.org/10.1177/0018726719846647

DOI: https://doi.org/10.35134/jbe.v7i1.68 